\title{
Security, Democracy, and the Rhetoric of Counter-Terrorism
}

\section{Richard Jackson}

Government and International Politics, School of Social Sciences, The University of Manchester, Manchester, United Kingdom

The "war on terrorism" is both a series of institutional practices and an accompanying set of political narratives. Employing the methodology of critical discourse analysis, the study suggests that the language of the "war on terrorism" is not simply a neutral or objective reflection of policy debates and the realities of terrorism and counterterrorism; rather, it is a very carefully and deliberately constructed public discourse that is specifically designed to make the war seem reasonable, responsible, and inherently "good." More importantly, as it is currently constructed, the language and practice of the "war on terrorism" poses severe challenges to the democratic state, including destabilizing the moral community, weakening democratic values and civic culture, undermining the legitimacy of democratic institutions, and preventing the articulation of potentially more effective counter-terrorism approaches.

\section{INTRODUCTION ${ }^{1}$}

The "war on terrorism" is both a set of institutional practices (military and intelligence operations, diplomatic initiatives, special government departments and security bodies, standard operating procedures, specific legislation, and so on), as well as an accompanying discursive project. That is, it is simultaneously a special political language of counter-terrorism with its own assumptions, symbolic systems, rhetorical modes and tropes, metaphors, narratives and meanings, and its own exclusive forms of knowledge. It is a distinct discourse, analogous to discourses in other fields-advertising, medicine, education, art, psychology, and the like. If we are to fully understand how the "war on terrorism" functions as a particular kind of political project, I believe that in addition to explaining its military, political, and economic dimensions, we must also appreciate how this particular discourse has been constructed

Richard Jackson is a Lecturer in International Security at The University of Manchester. His most recent book is Writing the war on terrorism: Language, politics and counterterrorism (Manchester University Press, 2005).

Address correspondence to Dr Richard Jackson, Government and International Politics, School of Social Sciences, The University of Manchester, Oxford Road, Manchester M13 9PL, United Kingdom. E-mail: Richard.jackson@manchester.ac.uk 
and how it functions to legitimize and normalize the institutional practices of counter-terrorism.

The analysis of public political discourse as a methodological approach reveals how some forms of knowledge are privileged over others, how identity is constructed and maintained, how power is legitimized, how political and institutional practices are normalized, and in this case, how social and political consensus is produced and reproduced ideationally. Political discourses are not neutral reflections of social and political reality; rather, they are partly constitutive of that reality - they have a reality-making effect. The practice of the "war on terrorism" in its military and political dimensions would not be possible without the accompanying language or discourse of counter-terrorism: discourse and practice are interdependent or co-constitutive. Moreover, political discourses possess a clear ideological character; they are the construction and deployment of "meaning in the service of power." Or, more specifically, discourses act as constructions of meaning that contribute to the production, reproduction, and transformation of relations of domination in society. ${ }^{3}$

Applying a critical discourse analysis (CDA) method, ${ }^{4}$ the primary phase of this research involved an examination of over 100 speeches of senior members of the Bush administration from September 11, 2001 to December 31, 2003. These texts were a representative sample of the more than 5,000 speeches, interviews, radio broadcasts, and press conferences on the subject of terrorism during this period. Included in this sample were speeches accorded symbolic importance, such as the Address to Congress and the American People on 20 September, 2001, the State of the Union Addresses, and anniversary and commemorative speeches. The remaining speeches were selected to include a range of speakers (as many senior administration officials as possible, as well as a sample of junior officials), and a range of dates covering the entire period.

The aim of the analysis was to uncover the primary discursive constructions at the heart of the "war on terrorism," to examine the ways in which the language of counter-terrorism has been produced, deployed, and reproduced in public political rhetoric, and to assess the effects of the discourse on democratic politics. The central argument is fairly simple. The language of the "war on terrorism" is not a neutral or objective reflection of policy debates and the realities of terrorism and counter-terrorism. Rather, it is a very carefully and deliberately constructed-but ultimately, artificial-discourse that was specifically designed to make the war seem reasonable, responsible, and "good," as well as to silence any forms of knowledge or counter-argument that would challenge the exercise of state power. More than merely public relations, "public diplomacy," or propaganda then, the effects of this discourse are to normalize, legitimize, and in a sense, actualize its institutional practice. More importantly, the discourse of the "war on terrorism", as it is presently 
constructed, poses severe challenges to the healthy functioning of democratic society.

\section{WRITING THE WAR ON TERRORISM}

The primary constructions of the administration's public discourse revolve around four main themes. First, and foundationally, the events of September 11, 2001 had to be discursively constructed and assigned a particular set of meanings; they did not "speak for themselves." Rather, the interpretation of "9-11" came to be fixed by the official discourse in such a way that it only had meaning in the context of certain officially accepted narratives. Second, the discourse constructed or re-affirmed new identities for both the victims-innocent, heroic and good Americans-, and the villains of the morality play-the evil, barbarous, and inhuman terrorists. Third, a central feature of the discourse involved the construction of the threat and danger of terrorism, which was re-made as immanent and catastrophic to democracy, freedom, civilization, and the American way of life; that is, it was reconstructed as a danger on the scale of Nazism and Communism. A fourth important aspect of the discourse involved the attempt to legitimize and normalize the quintessential "good war"-a popular narrative in American society and political discourse-as the primary response to these acts of terrorism (or "war").

There were, and still are, a variety of rhetorical and discursive strategies employed in these primary constructions. John Murphy argues that President Bush almost solely employed an epideictic rhetorical mode in his "war on terrorism" texts. That is, Bush's rhetoric "shapes the world that provides the backdrop of values and beliefs, heroes and villains, triumphs and tragedies against which and through which deliberative and forensic judgments are made in a ceaseless swirl of discourse." In keeping with this primary genre, the discourse relies on a powerful mix of analogy ("Al Qaeda is to terrorism what the mafia is to crime"), amplification (Al Qaeda wanted to "kill all Americans"), use of visual imagery (Bush carrying the "police shield of a man named George Howard who died at the World Trade Center trying to save others"), popular entertainment tropes (the "American hero"), foundational meta-narratives (Pearl Harbor and World War II, the fight for Civilization), and a ubiquitous over-arching Manichean frame (good versus evil, "either you are with us or you are with the terrorists").

What follows then, is a brief overview of the primary discursive constructions of the "war on terrorism"; a much more in-depth treatment can be found elsewhere. ${ }^{6}$ In the conclusion to the paper, I examine some of the most important features of the overall discourse and assess the particular dangers to democratic society of constructing counter-terrorism in this mode. 


\section{Constructing September 11, 2001}

When the Twin Towers collapsed, it appeared as if language itself also collapsed. There seemed to be no words to express what the events actually signified. In fact, acts of political violence never have clear or objective meanings; they have to be interpreted by political leaders to determine the appropriate response (Iraq's invasion of Iran in 1980 was not interpreted as a threat to America and the world; its invasion of Kuwait in 1990 was). Added to this, the live streaming images of the terrorist attacks, in a society characterized by a perennial sense of "hyper-reality," added to the loss of perspective. For many Americans, the sense that what they were seeing was a movie, but that it was even more 'real' than a movie, was a genuine concern. After all, most Americans had actually seen the destruction of New York before in countless disaster movies like Deep Impact, Final Fantasy, and AI. That is, the spectacle of the attacks fractured the common rhetorical resources of a society raised on a steady diet of virtual violence. Into this "void of meaning," 7 political leaders, particularly President George W. Bush, inserted a politically-driven narrative that has since come to dominate public interpretation of the events.

The most important aspects of this discursive construction of September 11, 2001 were that first, it was continuously made and re-made as a "national tragedy" (as opposed to a local tragedy), a "calamity," a "wound to the nation," and a "day that would never be forgotten." It was constantly re-affirmed as an exceptional grievance, and the signifier "9/11," torn from any temporal moorings, was immediately iconicised as the foremost symbol of American suffering. That is, by funneling the experience through the image of American exceptionalism while simultaneously claiming that the exceptional nature of the event placed it outside of normal political discourse, "9/11 quickly took on an exceptional ahistoricity." "None of this is to deny that it was genuine tragedy, but as any political entrepreneur knows, group grievance, national suffering and a sense of communal victim-hood provides one of the most potent means for legitimizing retaliatory counter-violence. There is little doubt that America's status of victim has since been effectively employed as a means of legitimizing military counter-violence and silencing opposition. As Donald Rumsfeld stated in response to a question about civilian casualties during bombing operations in Afghanistan: "There are going to be loss of life-there already have been. It started on September 11th in this building." Crucial to the maintenance of America's exceptional status as the primary victim was the decision by the television networks to avoid showing pictures of any bombed Afghan civilians.

A second, and perhaps the most important discursive sleight of hand in the construction of the attacks was its transformation from "despicable acts of terror" ${ }^{10}$ as Bush called it on September 11, 2001, to their rhetorical rebirth as an "act of war" in the following days. ${ }^{11}$ Such a rendering was central to placing 
it in an understandable "good war" narrative, and to justifying a war-based, rather than a criminal justice-based, counter-terrorist response. Of course, it would have been equally possible to re-affirm the attacks as terrorist assaults by a sub-state group of violent dissidents, criminal acts of mass murder, and crimes against humanity. Re-constructing them primarily as an "act of war" however, conferred on the state powers reserved for the supreme emergency, as well as domestic and international justification for military-based selfdefense.

A third aspect of the construction of the attacks was their discursive insertion into popular historical-political meta-narratives. De-coupled from their origins in the messy politics of the Middle East and the dark machinations of American foreign policy in Afghanistan, Iraq, Saudi Arabia, and Israel, and shorn from the history of a deepening spiral of violence and counter-violence between al Qaeda and American forces that had been ongoing since 1991, the attacks were reconstituted in terms more familiar and understandable to the American public. Very early on, the attacks were re-made in the mode of a World War II movie: they were "just like Pearl Harbor" ("September 11 was Pearl Harbor" according to one Congressman ${ }^{12}$ ), and the attackers were fascists and totalitarians akin to the Fascist Axis Powers. In a highly ironic twist, another World War II reference, "Ground Zero," was re-made as the site and symbol of America's victim-hood; no longer was it the place of ultimate Japanese suffering and American atrocity, it had now been reconstituted as a solely American narrative. In this usage, the term "ground zero," relies on an historical analogy which cannot be openly acknowledged because it would, among other things, destabilize the precariously established status of the United States as the primary victim. In other words, the term "both evokes and eclipses the prior historical reference, using it as a yardstick of terror-to claim that this was just like the horrific experience of a nuclear bomb-while at the same time consigning the prior reference to historical amnesia." 13 These discursive renderings made the attacks instantly understandable to a public immersed in the "good war" mythology of the Second World War, popularized over decades of movies and television programs such as From Here to Eternity, Thirty Seconds Over Tokyo, Patton, Schindler's List, Saving Private Ryan, Band of Brothers, U-571 and the blockbuster of 2001, Pearl Harbor. ${ }^{14}$

Related to this primary constitutive narrative of American identity, the attacks were also re-made as symbolic of the eternal struggle between the forces of "barbarism" and "civilization." The attacks of "9-11," as administration officials constructed them, drew a line between the "the civil and the savage," 15 between civilized people and the terrorists that "live on the hunted margins of mankind," 16 and between terrorism's values and the "values that separate us from animals - compassion, tolerance, mercy." 17 This meta-narrative actually has a long genealogy in international relations, ${ }^{18}$ which can be seen most recently in the so-called "clash of civilizations" discourse. ${ }^{19}$ In both popular 
culture and counter-terrorism discourse, terrorists are "the new barbarians," the epitome of savagery for the Western psyche. ${ }^{20}$ Linguistically, this trope is achieved through the natural functioning of the binary structure of language itself: employing the concept "civilization" instinctively brings to mind the opposite concept, "barbarism."

In its textual usage in political and social conversation, the civilizationbarbarism dichotomy has a number of different layers of meaning. For example, on one level it evokes images of menacing nomadic armies attempting to conquer Christian Europe. In the context of today's terrorists, it implies that "the behavior of these new 'barbarians' is uncontrollably guided by the same cruel instincts that motivated some of the most infamous 'barbarians' of past centuries, including Attila the Hun and the Mongol leader Genghis Khan." On another level, the civilization narrative is, for Americans at least, embedded into its foundational myths:

The myth represents American history as an Indian war, in which white Christian civilization is opposed by a "savage" racial enemy: an enemy whose hostility to civilization is part of its nature or fundamental character, an enemy who is not just opposed to our interests but to "civilization itself" $\ldots . .{ }^{22}$

In Freudian terms, we might say that the barbarians are representative of the id force: libidinous, irrational, violent, and dangerous. And at another but related level, the civilized Western world is contrasted with the violent and barbaric Eastern world. According to Said, it is a function of the way that our identity has been constructed; the Western person only exists as a contrast with the "Oriental" Other. ${ }^{23}$ In yet another language layer, globalization has come to be seen as the late-modern, sociological term for the "civilizing process." In this respect, terrorism-as a form of barbarism-can be seen as a challenge to international order and the civilizing process of globalization. ${ }^{24}$

Actually, the globalization meta-narrative is not so opaque; the events of September 11, 2001 are deliberately re-constructed as an attack on the global economic system. In his speech to the CEO Summit in Shanghai, emboldened by his proximity to the Great Wall of China (built to keep barbarians at bay), Bush states:

The stakes of this fight for all nations are high-our lives, our way of life, and our economic future. By attacking two great economic symbols, the terrorists tried to shatter confidence in the world economic system. [ . . . ] Terrorists want to turn the openness of the global economy against itself. We must not let them. ${ }^{25}$

Alan Greenspan, Chairman of the Federal Reserve, makes the discursive link even clearer. According to him, "Terrorism poses a challenge to the remarkable record of globalization"; moreover, "if we allow terrorism to undermine our freedom of action, we could reverse at least part of the palpable gains achieved by postwar globalization." ${ }^{26}$ In other words, "9/11" was an act of 
anti-globalization, as well as an act of war. It was "the battle of Seattle" in New York. This new layer of meaning helps to fill the void of meaning about the events with yet another contemporary and politically driven narrative.

In short, from an almost infinite universe of potential interpretations and meanings that could have been employed (a unique criminal conspiracy, a crime against humanity, "blowback" from earlier American policies, the latest phase of state-dissident violence and counter-violence, to suggest a few possibilities), through the careful use of key narratives and rhetorical strategies, the events of September 11, 2001 came to signify an extremely narrow set of political "truths": America had been attacked in an act of war by barbarians who were set on destroying America, globalization, and civilization itself; it was the start of a new, but familiar kind of war, in which America would fight new, but proverbial enemies.

\section{Constructing identities: evil terrorists and good Americans}

The realm of foreign policy, and particularly foreign adversaries, is enormously significant for "writing" identities. ${ }^{27}$ Foreign policy is critical for maintaining internal/external boundaries, and war (as a special form of foreign policy) plays a central role in maintaining the domains of inside/outside, foreign/ domestic, self/other. This is no less true for the "war on terrorism," which as we have suggested, is constructed largely in an epideictic rhetorical mode, rather than a deliberative mode. ${ }^{28}$ Bush makes appeals that attempt to unify the community and amplify its virtues; national character rather than national deliberation determine its actions. In fact, it has been argued that the very concept of the political self is based on the identification of the "enemy"; in other words, the enemy terrorist in the "war on terrorism" acts as the "enabling other" of the state-its negative justification. ${ }^{29}$ More than just identity maintenance then, the discourse of self and other in the rhetoric of counter-terrorism co-constitutes the political; it permits the state as practice.

Perhaps the most important feature of the construction of identity in this discourse is the ubiquitous use of a rhetorical trope of "good and evil." Deeply embedded in American rhetorical traditions and religious life (as well as being a sub-plot of the "civilization-barbarism" meta-narrative), this language essentializes the terrorists as both satanic and morally corrupt. On September 11, Bush stated that "Today, our nation saw evil, the very worst of human nature"; ${ }^{30}$ in subsequent texts, he frequently refers to terrorists as "the evil ones," and "evildoers." These are theological terms, deployed largely for a Southern conservative audience, but also appealing to popular entertainment understandings of "good guys" and "bad guys." As such, it is a demonological move in which the terrorists are individually and collectively marked as "cruel," "mad", and driven by "hate"; perhaps inadvertently, it also supernaturalizes them. In this agent/act ratio, the character of the terrorists precedes 
their actions: the terrorists did what they did because it is in their nature to do so- they murdered because that is what evil, demonic terrorists do. ${ }^{31}$ It is a powerful discourse, and an act of demagoguery, which de-contextualizes and de-historicizes the actions of the terrorists, emptying them of any political content, while simultaneously de-humanizing them. After all, there can be no deeper explanation for such acts, and there can be no reasoning or compromising with evil; the only right response is exorcism and purification. At the same time, the radical evil argument ${ }^{32}$ is a long used strategy of silencing liberal dissent: from Leo Strauss and Reinhold Neibuhr to Ronald Reagan, liberals have been charged with lacking both a realistic sense of human evil and the moral courage to confront it.

In an extension of re-making the attackers as demons, they are also scripted as inhuman or non-human. Bush speaks of the "curse of terrorism that is upon the face of the earth," 33 while Colin Powell refers to "the scourge of terrorism." 34 This medical metaphor is restated more explicitly by Rumsfeld: "We share the belief that terrorism is a cancer on the human condition." 35 Bush in turn, speaks of the danger to the body politic posed by "terrorist parasites who threaten their countries and our own." ${ }^{36}$ In this construction, the terrorist is remade as a dangerous organism that makes its host ill; they hide interiorly, drawing on the lifeblood of their unsuspecting hosts and spreading poison. This particular language is actually a precursor to the disciplinary idea of "the enemy within"; they are the new "reds under the bed." Of course, such "an evil and inhuman group of men"37_these "faceless enemies of human dignity"38_ are undeserving of our sympathy or protection. While it would be wrong to treat an enemy soldier inhumanely, or torture a criminal suspect, the same cannot be said for a parasite, a cancer, a curse. If the enemy is removed from the moral realm of human community, then by extension, actions towards them cannot be judged on moral terms. This is extremely liberating for a government fighting a hidden enemy, as it means that those government agencies that practice the "black arts" can be unleashed with impunity.

However, as if it were not enough to strip the enemy of all human features, the discourse also goes on to write them as fundamentally "alien" and "foreign." As John Ashcroft states:

Today I'm announcing several steps that we're taking to enhance our ability to protect the United States from the threat of terrorist aliens. [ . . . ] The Foreign Terrorist Tracking Task Force that Mr. McCraw will lead will ensure that federal agencies coordinate their efforts to bar from the United States all aliens who meet any of the following criteria: aliens who are representatives, members or supporters of terrorist organizations; aliens who are suspected of engaging in terrorist activity; or aliens who provide material support to terrorist activity. ${ }^{39}$

This designation of "alien terrorists" in particular, is the ultimate expression of "otherness" and is designed to clearly demarcate the boundaries between the 
inside and the outside, between those who belong to the community and those outside of it. In other words, not only are the terrorists disqualified from the domain of our community, they are disqualified from humanity itself. In a society immersed in the movie mythology of Invasion of the Body Snatchers, Alien, Independence Day, and The X-Files, the meanings of the term "alien terrorist" oscillate between "extra-terrestrial parasite" and "foreign enemy" without a hint of irony. After all, alien invasion movies are cultural metaphors for the fear of foreign invasion. Anthropologically, the trope of the evil/cancerous/ alien terrorist "monster"- the mode of composing social relations among terms-is actually the cultural projection of the tabooed "wild man" figure of the Western imagination. ${ }^{40}$ That is, rooted in the fundamental need to control dangerous behavior, taboos function to locate, identify, and segregate transgressions and dangers. In the absence of the (old) barbarians and the "red menace," terrorism now fulfills these functions to a tee.

On the other side of the identity coin, Americans are simultaneously constructed as being the polar opposite of the terrorist nature. The first major discursive inscription of the American character comes early on at the Prayer and Remembrance Day service on September 14, 2001. At this symbolically charged and constitutive pageant, Bush says:

In this trial, we have been reminded, and the world has seen, that our fellow Americans are generous and kind, resourceful and brave. We see our national character in rescuers working past exhaustion; in long lines of blood donors; in thousands of citizens who have asked to work and serve in any way possible. And we have seen our national character in eloquent acts of sacrifice. [ . . ] In these acts, and in many others, Americans showed a deep commitment to one another, and an abiding love for our country. Today, we feel what Franklin Roosevelt called the warm courage of national unity. This is a unity of every faith, and every background. ${ }^{41}$

In other words, Bush is constructing a new world of clearly demarcated characters: where terrorists are cruel, "the American people" are generous and kind; where terrorists are hateful, Americans are loving; where terrorists are cowardly, Americans are brave and heroic; and where terrorists hide and run, Americans are united. This highlighting and amplification is necessary to inscribe the essential qualities of insiders and outsiders, and plays through a movie-based mode of the simple opposites of "good guys and bad guys."

Another ubiquitous motif in the discourse is the 'hero' narrative, which again, is modelled on popular entertainment scripts. Every story in American popular culture has a cast of heroes and villains. The "war on terrorism" is no different: every EMS worker is Bruce Willis in Die Hard; every member of the armed forces is Tom Hanks in Saving Private Ryan; every ordinary citizen is Mel Gibson in The Patriot. Rumsfeld, in a memorial service the Pentagon victims, constructs these all-American heroes: 
We remember them as heroes. And we are right to do so. [ . . ] "He was a hero long before the eleventh of September," said a friend of one of those we have lost- "a hero every single day, a hero to his family, to his friends and to his professional peers." [ . . . ] About him and those who served with him, his wife said: "It's not just when a plane hits their building. They are heroes every day." "Heroes every day." We are here to affirm that. ${ }^{42}$

In one sense, this is simply national therapy-a way of giving meaning and respect to the lives lost. However, in its discursive function, it is also the inscription of the heroic Americans who are the opposite of the cowardly terrorists; it is the rendering of America's soldiers who are risking their lives to fight for the Homeland, freedom, and the safety of decent folk. Elevation to the status of hero is more than just leading by example, however; heroes are above criticism or moral judgment. Heroes are free to act as they see fit, even if it sometimes involves crossing the lines of public morality, and their shortcomings are quickly forgiven because by definition their motives are honest.

In summary, destroying the face of the terrorist, removing all traces of their personality or humanity, is essential to constructing the massive counter-violence of the "war on terrorism." After all, it would be far more difficult to bomb, torture, or hold in prison camps "enemy combatants" that were simply misguided, or psychologically ill, or commonly criminal. Simultaneously, the scripting of Americans as essentially "good" (and heroic, peaceful, innocent) is a means of reassurance: whatever Americans do is good and right, because it is their nature to be good-even if on the face of it, the victims of September 11, 2001 look strikingly similar to the victims of October 7, 2001.

\section{Constructing threat and danger}

As David Campbell has shown, discourses of danger and foreign threat have been integral in constituting and disciplining American identity as practiced through its foreign policy. ${ }^{43}$ Collectivities, especially those as disparate and diverse as America, are often only unified by an external threat or danger; in this sense, threat creation can be functional to political life. Historically, the American government has relied on the discourse of threat and danger on numerous occasions: the "red scares" of the native Americans who threatened the spread of peaceful civilization along the Western frontier, the workers' unrest at the time of the Bolshevik Revolution, and the threat to the American way of life during the cold war; the threat of "rogue states" like Libya, Panama, Iran, North Korea, and Iraq; and the threats posed by the drug trade, the proliferation of weapons of mass destruction, and now of course, terrorism. These discourses of danger are scripted for the purposes of maintaining inside/ outside, self/other boundaries-they write American identity-and for enforcing unity on an unruly and (dis)United States. 
Of course, there are other more mundane political functions for constructing fear and moral panic: provoking and allaying anxiety to maintain quiescence, de-legitimizing dissent, elevating the status of security actors, diverting scarce resources into ideologically driven political projects, distracting the public from more complex and pressing social ills. ${ }^{44}$ This is not to say that terrorism poses no real threat; the dangers can plainly be seen in the images of falling bodies and the piles of rubble. Rather, it is to point out that dangers are those facets of social life interpreted as threats (in one sense, dangers do not exist objectively, independent of perception), and what is interpreted as posing a threat may not always correspond to the realities of the actual risk of harm. Illegal narcotics, for example, pose less of a risk than the abuse of legal drugs, but a "war on drugs" makes it otherwise. Similarly, the "war on terrorism" is a multi-billion dollar exercise to protect Americans from a danger that, excluding the September 11, 2001 attacks, killed less people per year over several decades than bee stings and lightening strikes. Even in 2001, America's worst year of terrorist deaths, the casualties from terrorism were still vastly outnumbered by deaths from auto-related accidents, gun crimes, alcohol and tobacco-related illnesses, suicides, and a large number of diseases like influenza, cancer, and heart disease. Globally, terrorism, which kills a few thousand per year, pales into insignificance next to the 40,000 people who die every day from hunger, the half a million people who die every year from small wars, the 150,000 annual deaths from increased diseases caused by global warming, ${ }^{45}$ and the millions who die from AIDS. And yet, the whole world is caught up in the global "war on terrorism" whose costs so far run into the hundreds of billions. In a world of multiple threats, many of which pose a far greater risk to individual safety, the fact that terrorism is widely seen as posing the greatest and most immediate threat is due to the deliberate construction of a discourse of danger.

The initial construction of the threat of terrorism involved fixing the attacks of 9/11 as the start of a whole new "age of terror," rather than as an extraordinary event, or an aberration (out of 18,000 terrorist attacks since 1968 only a dozen or so have caused more than 100 deaths; high-casualty terrorist attacks are extremely rare and 9/11 was the rarest of the rare). Instead, the attacks were interpreted as the dawning of a new era of terrorist violence that knew no bounds. As Bush stated, "All of this was brought upon us in a single day-and night fell on a different world." ${ }^{\text {66 }}$ Vice-President Dick Cheney made it even clearer:

Today, we are not just looking at a new era in national security policy, we are actually living through it. The exact nature of the new dangers revealed themselves on September 11, 2001, with the murder of 3,000 innocent, unsuspecting men, women, and children right here at home. ${ }^{47}$

This construct was only possible by severing all links between this act of terrorism and countless others that had preceded it, and by de-contextualizing it 
from the history of al Qaeda's previous attacks. As we saw earlier, "9/11" was constructed without a pre-history; it stands alone as a defining act of cruelty and evil. This break with the past makes it possible to assign it future significance as the start of "super-terrorism," "catastrophic terrorism," or simply "the new terrorism." Logically, if there's a new super-terrorism, then a new super-war-on-terrorism seems reasonable.

A second feature of this discourse of danger is the hyperbolic language of threat. It is not just a threat of sudden violent death, it is actually a "threat to civilization," a "threat to the very essence of what you do," 48 a "threat to our way of life," 49 and a threat to "the peace of the world." 50 The notion of a "threat to our way of life" is a Cold War expression that vastly inflates the danger: instead of a tiny group of dissidents with resources that do not even begin to rival that of the smallest states, it implies that they are as powerful as the Soviet empire was once thought to be with its tens of thousands of missiles and its massive conventional army. Moreover, as Cheney reminds us, the threat of terrorism, like the threat of Soviet nuclear weapons, is supremely catastrophic:

The attack on our country forced us to come to grips with the possibility that the next time terrorists strike, they may well be armed with more than just plane tickets and box cutters. The next time they might direct chemical agents or diseases at our population, or attempt to detonate a nuclear weapon in one of our cities. [ . . . ] no rational person can doubt that terrorists would use such weapons of mass murder the moment they are able to do so. [ . . . ] we are dealing with terrorists [ ...] who are willing to sacrifice their own lives in order to kill millions of others. ${ }^{51}$

In other words, not only are we threatened by evil terrorists eager to kill millions (not to mention civilization itself, the peace of the world, and the American way of life), but this is a rational and reasonable fear to have. We should be afraid, very afraid: "If they had the capability to kill millions of innocent civilians, do any of us believe they would hesitate to do so?."52

As if this was not enough to spread panic throughout the community, officials then go to great lengths to explain how these same terrorists (who are eager to kill millions of us) are actually highly sophisticated, cunning, and extremely dangerous. As John Ashcroft put it: "The highly coordinated attacks of September 11 make it clear that terrorism is the activity of expertly organized, highly coordinated, and well-financed organizations and networks." 53 Moreover, this is not a tiny and isolated group of dissidents, but "there are thousands of these terrorists in more than 60 countries" and they "hide in countries around the world to plot evil and destruction"; 54 or, like the plot of a popular novel: "Thousands of dangerous killers, schooled in the methods of murder, often supported by outlaw regimes, are now spread throughout the world like ticking time bombs, set to go off without warning." 55 In other speeches, officials inflate the numbers of the terrorists to "tens of thousands" of killers spread throughout the world. 
The next layer of fear is the notion that the threat resides within; that it is no longer confined outside the borders of the community, but that it is inside of us and all around us. As Ashcroft constructs it:

The attacks of September 11 were acts of terrorism against America orchestrated and carried out by individuals living within our borders. Today's terrorists enjoy the benefits of our free society even as they commit themselves to our destruction. They live in our communities - plotting, planning, and waiting to kill Americans again [ ... ] a conspiracy of evil. ${ }^{56}$

Like the "red scares" of the past, the discourse of danger is deployed in this mode to enforce social discipline, mute dissent, and increase the powers of the national security state. It is designed to bring the war home, or, as Bush puts it: "And make no mistake about it, we've got a war here just like we've got a war abroad." 57

In another genealogical link to previous American foreign policy, the threat of terrorism is from a very early stage reflexively conflated with the threat of "weapons of mass destruction" and the "rogue states" who might hand them on to terrorists. According to the discourse, rogue states are apparently eager to assist terrorists in killing millions of Americans. As Bush stated in his now infamous "axis of evil" speech,

States like these, and their terrorist allies, constitute an axis of evil, arming to threaten the peace of the world. By seeking weapons of mass destruction, these regimes pose a grave and growing danger. They could provide these arms to terrorists, giving them the means to match their hatred..$^{58}$

This is actually an ingenious discursive slight of hand which allows America to re-target its military from a war against a tiny group of individual dissidents scattered across the globe, to territorially defined states who also happen to be the target of American foreign policy. It transforms the "war against terrorism" from a largely hidden and unspectacular intelligence gathering and criminal apprehension program, to a flag-waving public display of awesome military firepower that re-builds a rather dented American self-confidence. More importantly, it allows for the simultaneous pursuit of geo-strategic objectives in crucial regions such as the Middle East under the banner of the "war on terrorism." 59

Instead of reassuring the nation that the attacks were an exceptional and a unique event in a long line of terrorist attacks against America (that have thus far failed to overthrow freedom), the Bush administration chose instead to construct them as the start of a whole new age of terror-the start of a deadly new form of violence directed at Americans, civilized people all over the world, freedom, and democracy. The Bush administration could have chosen to publicize the conclusions of the Gilmore Commission in 1999, a Clintonappointed advisory panel on the threat of WMD falling into the hands of 
terrorists. Its final report concluded that "rogue states would hesitate to entrust such weapons to terrorists because of the likelihood that such a group's actions might be unpredictable even to the point of using the weapon against its sponsor," and they would be reluctant to use such weapons themselves due to "the prospect of significant reprisals." ${ }^{60}$ Condoleeza Rice herself wrote in 2000 that there was no need to panic about rogue states, because "if they do acquire WMD-their weapons will be unusable because any attempt to use them will bring national obliteration."61 Instead, officials engaged in the deliberate construction of a world of unimaginable dangers and unspeakable threats; they encouraged social fear and moral panic. Within the suffocating confines of such an emergency, where Americans measure their daily safety by the color of a national terrorist alert scale (reflected in the glow of every traffic light), it seems perfectly reasonable that the entire resources of the state be mobilized in defense of the homeland, and that pre-emptive war should be pursued. It also seems reasonable that national unity be maintained and expressions of dissent curtailed.

The reality effect of scripting such a powerful danger moreover, can be seen in the two major wars fought in two years (followed by costly ongoing "security operations" in each of those states to root out the terrorists), the arrest of thousands of suspects in America and around the world, and the vast sums spent unquestioningly (even by the Democrats) on domestic security, border control and the expansion of the military. Only the "reality" of the threat of terrorism allows such extravagance; in fact, the manner in which the threat has been constructed-catastrophic, ubiquitous, and ongoing-normalizes the entire effort. If an alternative interpretation of the threat emerged to challenge the dominant orthodoxy (that it was vastly over-blown, or misdirected, for example), support for the consumption of such massive amounts of resources might be questioned and the political order destabilized. A massive threat of terrorism then, is necessary for the continued viability of the "war on terrorism"; writing the threat of terrorism is co-constitutive of the practice of counter-terrorism.

\section{Constructing the "good war"}

By this stage, the "war on terrorism" has already been powerfully constructed as the quintessential good war: ${ }^{62}$ apart from its conflation with the "good war" meta-narratives of World War II, the Cold War and the battle for civilization, it is also continuously reproduced as a Manichean struggle between good and evil, and a rational response to the extreme dangers posed by terrorism. However, in a "theo-political" atmosphere, ${ }^{63}$ where a fundamentalist Christian president speaks to nineteen million Christian Right voters (the single most influential voting bloc in America), a "good war" is not nearly enough-it must also be a divinely sanctioned war. Tapping into the deep well-spring of American religiosity as a means of solidifying support, the "war 
on terrorism" is given God's blessing by its careful construction as a traditional Just War. That is, officials construct the war as having a just cause, as being properly conducted, as being a last resort, and as being winnable.

In the first place, the war is re-molded from a counter-terrorist operation to a Just War with a clear casus belli, namely, bringing the perpetrators to "justice." As Bush nonsensically expressed it, "Whether we bring our enemies to

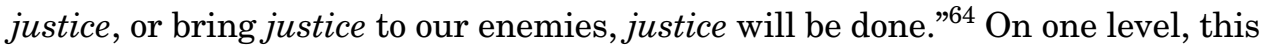
conflates America's actions with the divine purpose. In the same speech, Bush stated: "Freedom and fear, justice and cruelty, have always been at war, and we know that God is not neutral between them." side of "justice"; America is bringing "justice"; therefore, by definition, God is on America's side. In part, it is this assertion of universal values and divine calling that led the Bush administration to initially call the Afghan campaign "Infinite Justice"; more than simply a slip of the tongue, as it was later claimed, it was the logical choice for the construction of a Just War. On another level, framed in the language of the American frontier (note the use of Wanted Dead or Alive posters and bounties, the "Most Wanted Terrorists" featured on the popular television program America's Most Wanted, and Bush's cowboy boots), the campaign in Afghanistan to "smoke them out of their holes"66 fits easily into America's rich mythology of redemptive violence; it is Shane, John Wayne, or Clint Eastwood exacting revenge, enforcing a kind of natural justice and ridding the West of dangerous villains so that decent folk can rest safe.

In addition to bringing justice, the war's just cause is reaffirmed by its status as a war of self-defense. This is the traditional means by which states assert their right to wage war; wars of aggression are by definition wrong, but wars of self-defense are fully justified. As Under Secretary of State Marc Grossman, constructed it:

I believe that Security Council resolution 1368 that was passed on the 12 th of September, offers all of the legal basis and requirement that we need, in addition to Article 51 of the United Nations Charter, which is the right of self-defense. And we believe the United States was attacked on the 11th of September and that we have a right of self-defense in this regard. ${ }^{67}$

Rumsfeld repeats this construction by appealing to the universal right of every nation to self-defense: "there is no question but that any nation on earth has the right of self-defense. And we do." ${ }^{68}$ In other words, it is a Just War because it is legally sanctioned by the authority of international law. Importantly, the choice of legal arguments for attacking Afghanistan was in itself highly strategic: going for UN legal justification in terms of self-defense rather than Chapter VII action provided a greater freedom to maneuver and avoided existing and constraining precedents. ${ }^{69}$ In either case, both of these reasonsbringing justice or self-defense-qualify as acceptable reasons for war according to traditional Just War Theory. 
In addition to the construction of its just cause, the war on terrorism is framed in the language of Just War Theory by its claims to be properly conducted, with proportionality and due care for the lives of innocent civilians. As American officials constantly reiterated:

I know for a fact that we are just being enormously careful. We are doing everything humanly possible to try to avoid collateral damage. ${ }^{70}$

Afghanistan proved that expensive precision weapons defeat the enemy and spare innocent lives, and we need more of them. ${ }^{71}$

Obviously, a war that does not just take care to try and avoid civilian casualties but actually saves innocent lives is a rightly conducted war. Grossman actually puts the case positively: "I believe, sir, that when there is a fair and accurate representation when this campaign is over, we will find that the number of civilian casualties actually has been very, very low." ${ }^{\text {"2 Rumsfeld }}$ goes even further: "I can't imagine there's been a conflict in history where there has been less collateral damage, less unintended consequences."73 In other words, the whole debate over the conduct of the war is moot because so few civilians will be, or have been killed; a war with so few civilian deaths makes it a truly Just War-perhaps it is the first truly Just War in history.

Just War Theory also states that wars should only be undertaken as a last resort after all other avenues have been explored. It is thus a prominent feature of the discourse that there is no peaceful alternative to a "war on terrorism." As Bush put it: "the only way to defeat terrorism as a threat to our way of life is to stop it, eliminate it, and destroy it where it grows"; 74 and "In the face of today's new threat, the only way to pursue peace is to pursue those who threaten it."75 Moreover, unlike previous enemies (or perhaps like previous enemies), "Those who hate all civilization and culture and progress, those who embrace death to cause the death of the innocent, cannot be ignored, cannot be appeased. They must be fought."76 This is an oblique World War II reference to the appeasement of Hitler; its meaning is simply that there can be no peaceful solution when facing such enemies. War is the only resort, much less the last resort. Such a rendering places the justifications for the war firmly within the precepts of Just War Theory.

Another Just War precept is that any war undertaken must have a reasonable chance of success in order to minimize suffering. From the very beginning, the "war on terrorism" was discursively constructed as ultimately winnable. Bush stated on September 11, 2001, "we stand together to win the war against terrorism." ${ }^{\prime 7}$ In addressing the final outcome of the war, the grammatical form is always unequivocally a statement of fact rather than opinion: "we will win this conflict by the patient accumulation of successes"; 78 "We will fight for as long as it takes, and we will prevail";79 "And on the home front, terrorist violence must be prevented, and must be defeated. And it will be." ${ }^{80}$ In fact, when asked about the length of the war-a direct reference to the chances of winning in 
a reasonable period of time-Bush replied: "People often ask me, how long will this last? This particular battlefront will last as long as it takes to bring al Qaeda to justice. It may happen a month from now; it may take a year or two. But we will prevail." 81 There is no question about the outcome, even if the timeframe is a little vague. In this case, the certainty of victory rhetorically overwhelms the uncertainty over the length of the campaign; the end result_triumph-is more important than the time it takes to get there.

However, in the end, the "good war" on terrorism falls victim to its inbuilt contradictions and has to be reflexively reconstituted as a "new kind of war"; it becomes instead a "good new war." As Bush constructs it, "the world has come together to fight a new and different war, the first, and we hope the only one of the $21^{\text {st }}$ century." 82 In the same speech, he argues that "This is a different kind of war that requires a different type of approach and different type of mentality." This re-writing is necessary because a Just War, properly constituted and conducted, requires adherence to the laws of war-the proper treatment of captured enemy soldiers, defensible grounds for attacking weaker nations, and proper sanction by the governing institutions of international society. In this, it also requires recognition of the enemy as legitimate purveyors of violence-as warriors rather than as demons or barbarians. Such a descriptor obviously does not sit comfortably with the notion of evil and inhuman terrorists. Thus, the war on terrorism had to be re-written as a "new" and "different" war, one with new kinds of enemies- "unlawful combatants" — who could be subjected to treatment prohibited to legitimate warriors and soldiers (indefinite internment, subject to torture "lite", trial by military courts, extradited to countries without prohibitions on the use of torture, and so on). In this context, Bush explains his creation of a new legal category:

I have also reserved the option of trial by military commission of foreign terrorists who wage war against our country. Non-citizens, non-U.S. citizens who plan and/or commit mass murder are more than criminal suspects. They are unlawful combatants who seek to destroy our country and our way of life. And if I determine that it is in the national security interest of our great land to try by military commission those who make war on America, then we will do so. ${ }^{83}$

In other words, within the textual world of the "new" war on terrorism, the contradictions involved in denying enemy soldiers any rights under the Geneva Conventions or the criminal justice system are reconciled. It is a powerful rhetorical strategy that can be reflexively and retroactively employed to justify and explain almost any unsavory aspect of this "good war" that comes to light. More than simply the treatment of prisoners then, this construction provides policy-makers with a great deal of flexibility in dealing with any inherent tensions of the discourse: whatever does not fit the traditional conception of the "good war" can be explained away as a necessity of the "different kind of war" now being fought. This is how indefinite detention and the suspension of 
habeas corpus, black operations and assassinations on foreign soil, the massacre of Taliban prisoners in Afghanistan, providing material and political support to abusive authoritarian regimes, using Watergate-style dirty tricks on Security Council members, and other morally suspect methods, are rhetorically washed clean and baptized into the good and just "war on terrorism."

\section{CONCLUSION}

There are a number of significant and interesting aspects to this discourse. Obviously, it is an extremely powerful discourse that has normalized a particular approach to counter-terrorism which is for the most part, uncritically accepted and unquestioned except in its application. Even the opposition Democrats do not question the necessity of a "war on terrorism"; rather, their main concern is whether attacking Iraq was the right strategy at the time. The current ideological hegemony of the discourse is aided by its relatively unmediated reproduction in the American media (and parts of the global media), and by its almost verbatim reproduction by the leaders of coalition partners, such as Blair and Howard. In fact, the media has been highly complicit in the reproduction of the discourse; even the most uncritical appraisal of opinion polls reveals how successful it has been in promoting support for counter-terrorism, the linking of 9-11 and the Iraqi "rogue state," the constant fear of attack, and consequently, the exercise of American military power.

Additionally, the genealogy of the current "war on terrorism" demonstrates clear lines of continuity with the earlier "wars on terrorism" declared by the Reagan and Clinton administrations. Following on from each other, both leaders constructed terrorism as the greatest threat to American and international security, and both attacked "rogue states" in the Middle East as a response: Libya in Reagan's "war on terrorism," Sudan and Afghanistan in Clinton's. Now of course, Bush has followed suit in Afghanistan and Iraq. Reagan, like Bush, referred to "the evil scourge of terrorism" which was a plague spread by the "depraved opponents of civilization itself"; Secretary of State, George Shultz, said that terrorism was "a return to barbarism in the modern age." 84 Far from unique then, the discourse of the "war on terrorism" follows long established interpretive dispositions towards the international sphere: a zero-sum attitude towards international action, a tendency to militarize foreign policy responses, a fear of internal subversion, and a sense of endangerment towards "the other." ${ }^{85}$ In other words, part of the reason why the discourse has been so uncritically accepted (particularly domestically) is because it is built on the logic of previous American responses to similar crises. Related to this, the discourse is noteworthy for its hybridity, and the ease with which it weaves disparate narratives into a single seamless story of the good fight against terrorism/barbarism/evil. The language powerfully combines World War II, Civilization Versus Barbarism, Good Versus Evil, and 
Just War narratives into a new super-narrative-a textual symphony-that legitimizes and normalizes the practice of American domestic and foreign policy. These powerful discursive combinations provide the authorities with multiple possibilities for disciplining subjects, allies, and enemies.

In terms of its rhetorical strategies, tropes and modes, the discourse is noted for its reliance on an epideictic presidential style, its popular narratives and its overall movie-like script. In this screenplay, familiar entertainment themes are deployed for political effect: the myth of redemptive (Westernstyle) violence and popular hero narratives (the EMS and "everyman" heroes of 9-11, the heroic armed forces, Saving Private Jessica Lynch) are played out in war movie narrative structure by a compliant media (on CNN screens, the banners told the story of "America under Attack," "America Strikes Back," "America's New War" and "America Recovers"). The use of these tropes in public discourse taps into a whole reservoir of cultural forms and meanings that provide political resources that are unavailable within the normal liberaldemocratic vocabulary. ${ }^{86}$ The power of the ubiquitous epideictic rhetoric therefore, is that it creates a new epistemic and symbolic world that provides the backdrop of values, beliefs and identities against which and through which officials make policy and act politically. ${ }^{87}$

However, the discourse is also distinguished by its inherent instabilities, and the reflexivity required to maintain internal coherence: it is a war, but not a war like any other ever fought; it is fundamentally about protecting freedom, except for those suspected of terrorist activities; it is to preemptively deal with "immanent" threats like Iraq, or maybe only "potential" threats (like Iraq); it is an historic calling to spread the values of democracy and freedom, except for those states strategically important in fighting terrorism (such as Saudi Arabia, Pakistan, Uzbekistan, Russia); it is a good war except when bad methods have to be employed because it is a new war; and so on. In other words, the discourse is not invulnerable and counter-hegemonic struggle is possible through a strategy of deconstruction and attacking its inconsistencies and contradictions.

Of course, it is not enough to simply observe the way language and meaning is produced, deployed, used, and misused in public discourse; there are also very real dangers involved that must be acknowledged and addressed. For example, there is a real danger that the discourse relies on an approach to counter-terrorism that has historically proved to be of limited effectiveness, and through the privileging of some forms of knowledge over others, excludes other potentially more effective counter-terrorist strategies; in short, the risk is that the moral absolutism of the discourse induces political amnesia. ${ }^{88}$ Related to this, there is a danger that the discourse is actually misconceiving and misunderstanding the nature of the threat-that it is poor "threat assessment," to use military parlance. By failing to understand the history and context of terrorism, the actual nature and causes of terrorism, and the real 
motivations and aims of the terrorists (who are most certainly not sacrificing their lives in suicidal attacks simply for the sake of "evil"), we may seriously damage the search for more effective and long-term policy solutions. Moreover, the hegemony of the current discourse may mark out the meaning and role of counter-terrorist policies for decades to come, regardless of their actual impact on societal and individual security.

Another very real danger is that the "war on terrorism," as it is currently constructed and practiced, is actually making international terrorism worse through entrenching cycles of violence and counter-violence; that just as has already occurred in Israel, Chechnya, Kashmir, Colombia, Iraq, Algeria, Spain, and other places, it is making the world less secure, more violent, and more unjust, and creating self-fulfilling prophesies-where "terrorism foretold must become prophesy fulfilled at some point." ${ }^{89}$ In other words, there is a risk of constructing a situation of perpetual war where terrorism and counterterrorism become indistinguishable; where the discursive practices of a "war on terrorism" echo and mimic the very absolutist mentality and exceptionalist tactics of the terrorists themselves. Moreover, there is a very real danger that the "war on terrorism" may damage our own societies through weakening democratic values and undermining the legitimacy of democratic institutions (such as the judicial system, the police and the security services). Historically, the construction and reproduction of the "security state" almost inevitably leads to a narrowing of civic culture and political life-the constriction of politics through demonising an ever-widening variety of dissent. ${ }^{90}$ Related to this, the creation of moral panics can victimize minorities and inflame inter-ethnic tensions, at the same time as they militarize society and normalize state intrusion and coercion. In short, the danger is that the "war on terrorism" becomes a "war of terrorism".

More importantly, the discourse and practice of counter-terrorism can lead to the de-legitimizing of dissent and the narrowing of the discursive space for political debate. Already, conservatives have attacked anti-globalization protesters, academics, postmodernists, liberals, pro-choice activists, environmentalists, and gay liberationists as being aligned with terrorism and its inherent evil. ${ }^{91}$ The moral taxonomy of the good versus evil construction in particular, is extremely corrosive of democratic politics because it undermines the possibility of a loyal opposition. ${ }^{92}$ Moreover, the invocation of evil is a powerful tool for ending arguments and displacing more complex understandings of political and social events; the suffocating logic of the discourse makes it exceedingly difficult to think clearly about the terrorist attacks and the counter-terrorist war that has followed. ${ }^{93}$ This may not signal the return of McCarthyism or the "end of politics" quite yet, but there is little doubt that the body politic is starting to show signs of sickness.

Finally, there are real dangers for the stability of the international system itself. For instance, there is the danger of de-stabilizing already unstable 
regions through the application of pre-emptive war doctrines (the operative conclusion of the discourse) by states that are currently fighting insurgencies and terrorist campaigns. Many of these states-Russia, China, Algeria, India, Israel, Macedonia, Malaysia, Indonesia, Zimbabwe-have already re-framed their struggles against internal dissidents as local "wars on terrorism" as a way of both muting international criticism and garnering fresh support. Additionally, there is little doubt that the Iraq war phase of the "war on terrorism" has undermined institutions of global governance, particularly the United Nations, and the conduct of US forces and military doctrines are re-asserting exclusivist communitarian values (it is the duty and right of every state to value the lives of its own citizens above the lives of all others) over cosmopolitan values.

If these and other dangers are to be avoided, we must first reclaim the right to question and debate the profound policy issues that lie at the heart of the "war on terrorism," and challenge the normative foundations of counterterrorist violence. In large part, such an engagement will only be possible when the deconstruction of the discursive straightjacket we are currently trapped within begins in earnest.

\section{NOTES}

1. An earlier version of this paper was presented at the International Studies Association (ISA) Annual Convention, 18-20 March, 2004, Montreal, Canada.

2. N. Fairclough, Media discourse (London: Edward Arnold, 1995), 14.

3. N. Fairclough, Discourse and social change (Cambridge: Polity Press, 1992), 87.

4. CDA is at once both a technique for analyzing specific texts or speech acts, and a way of understanding the relationship between discourse and social and political phenomena. By engaging in concrete, linguistic textual analysis-that is, by doing systematic analyses of spoken and written language-CDA aims to shed light on the links between texts and societal practices and structures, or, the linguistic-discursive dimension of social action. In addition, because individual text analysis is not sufficient on its own to shed light on the relationship between discourse and social processes, CDA adds a wider inter-disciplinary perspective which combines textual and social-political analysis. Further explanation of the methodology employed here can be found in Richard Jackson, Writing the War on Terrorism: Language, politics and counter-terrorism (Manchester: Manchester University Press, 2005). A thorough explanation of the CDA approach to political research can be found in Marianne Jorgensen and Louise Phillips, Discourse Analysis as Theory and Method (London: Sage, 2002).

5. John Murphy, “Our mission and our moment”: George W. Bush and September 11,' Rhetoric and Public Affairs 6: 4, 2003, 610.

6. See Jackson, Writing the War on Terrorism.

7. David Campbell, "Time is broken: The return of the past in the response to September 11," Theory \& Event 5: 4, 2002.

8. Original emphasis, James Der Derian, "In Terrorem: Before and after 9/11," in Ken Booth and Tim Dunne, eds., Worlds in collision: Terror and the future of global order, (New York: Palgrave Macmillan, 2002), 102. 
9. Unless stated otherwise, all emphasis within official quotations have been added to indicate the basis of claims. Donald Rumsfeld, Secretary of Defense, Interview with editorial board of USA Today, News Transcript from the United States Department of Defense, October 24, 2001. All administration speeches quoted in this paper can be accessed from: http://usinfo.state.gov/topical/pol/terror/.

10. President George W. Bush, Statement by the President in his address to the nation, September 11, 2001.

11. See President George W. Bush, President's Remarks at National Day of Prayer and Remembrance, the National Cathedral, Washington, D.C., September 14, 2001; and George Bush, Secretary of State Colin Powell, and Attorney General John Ashcroft, Remarks at Camp David, September 15, 2001.

12. Tom Lantos (Representative, Democrat, California), "Statement on fighting terrorism," 10 October, 2001.

13. Amy Kaplan (2003) "Homeland insecurities: Reflections on language and space," Radical History Review, 85, 84.

14. See Tom Pollard, "The Hollywood war machine", in Carl Boggs, ed., Masters of war: Militarism and blowback in the era of American empire, (New York and London: Routledge, 2003).

15. John Ashcroft, Attorney General, Testimony to House Committee on the Judiciary, September 24, 2001.

16. George W. Bush, Remarks by the President to the CEO Summit, Pudong ShangriLa Hotel, Shanghai, People's Republic of China, October 20, 2001.

17. Howard H. Baker, Jr., U.S. Ambassador, Japanese Observance Ceremony for Victims of Terrorism in the U.S., September 23, 2001, Tokyo.

18. See M. Salter, Barbarians and civilization in international relations (London: Pluto Press, 2002).

19. See K. A. El Fadl, "Introduction," in K. A. El Fadl, ed., Shattered Illusions: Analyzing the War on Terrorism (Bristol: Amal Press, 2002).

20. Joseba Zulaika and William A. Douglass, Terror and taboo: The follies, fables, and faces of terrorism (New York and London: Routledge, 1996), 156.

21. M. Llorente "Civilization versus barbarism," in J. Collins and R. Glover, eds., Collateral language: A user's guide to America's new war (New York: New York University Press, 2002), 41, 45.

22. Slotkin 2001, quoted in Z. Sardar and M. W. Davies, Why do people hate America? (Cambridge: Icon Books, 2002), 190-191.

23. Edward Said, Orientalism (New York: Pantheon Books, 1978).

24. M. V. Rasmussen, “A parallel globalization of terror”: 9-11, security and globalization," Cooperation and conflict 37: 3, 2002, 337.

25. Bush, CEO Summit, Shanghai, 20 October, 2001.

26. Alan Greenspan, Chairman of the Federal Reserve, Remarks at the Institute for International Economics' Inauguration of the Peter G. Peterson Building, Washington, D.C., October 24, 2001.

27. See David Campbell, Writing security: United States foreign policy and the politics of identity, Revised edition, (Manchester: Manchester University Press, 1998).

28. See Murphy, “Our mission and our moment". 609. 
29. See Samuel Weber, "War, terrorism, and spectacle: On towers and caves", The South Atlantic Quarterly 101: 3, 2002, p. 452.

30. Bush, Address to the Nation, 11 September, 2001.

31. See Murphy, "Our mission and our moment," 616.

32. James Aune, "The argument from evil in the rhetoric of reaction," Rhetoric and public affairs 6: 3, 2003, 518-522.

33. Bush, Powell Ashcroft, Remarks at Camp David, September 15, 2001.

34. Colin L. Powell, Remarks by the Secretary of State to the National Foreign Policy Conference for Leaders of Nongovernmental Organisations (NGO), October 26, 2001, Loy Henderson Conference Room, U.S. Department of State, Washington, D.C.

35. Donald H. Rumsfeld, Secretary of Defense, and Joint Chiefs of Staff, Gen. Richard Myers, Briefing on Enduring Freedom, The Pentagon, October 7, 2001.

36. George W. Bush, The State of the Union Address, Washington, January 29, 2002.

37. Baker, Japanese Observance Ceremony, 23 September, 2001.

38. George W. Bush, Remarks in Commencement Address To United States Coast Guard Academy, Nitchman Field, New London, Connecticut, May 21, 2003.

39. John Ashcroft, Attorney General, News Conference with Immigration and Naturalization Service Commissioner James Ziglar, and Steve McCraw, newly appointed director Foreign Terrorist Tracking Task Force, Department of Justice Conference Center, October 31, 2001.

40. See Zulaika and Douglass, Terror and taboo.

41. Bush, National Day of Prayer and Remembrance, 14 September, 2001.

42. Donald H. Rumsfeld, Secretary of Defense, Remarks at a Memorial Service in Remembrance of Those Lost on September 11th, The Pentagon, Arlington, VA Thursday, October 11, 2001.

43. Campbell, Writing Security.

44. See Robert Hariman, "Speaking of evil", Rhetoric and public affairs 6: 3, 2003, 511-517; Murray Edelman, The symbolic uses of politics (Urbana: University of Illinois press, 1964); Barry Glassner, The culture of fear: Why Americans are afraid of the wrong things (New York: Basic Books, 1999).

45. See Mark Lynas "Essay: The sixth mass extinction," New Statesman, 23 February, 2004.

46. George W. Bush, Address to a Joint Session of Congress and the American People, September 20, 2001.

47. Dick Cheney, Vice-President, Remarks to the American Society of News Editors, The Fairmont Hotel, New Orleans, April 9, 2003.

48. Powell, Remarks to the National Foreign Policy Conference, 26 October, 2001.

49. Bush, Address to a Joint Session, 20 September, 2001.

50. Bush, State of the Union Address, 29 January, 2002.

51. Cheney, Remarks to the American Society of News Editors, 9 April, 2003.

52. Paul Wolfowitz, Deputy Secretary of Defense, Prepared Testimony: "Building a military for the 21st century," To the Senate Armed Services Committee, October 4, 2001.

53. Ashcroft, Testimony to House Committee, 24 September, 2001. 
54. Bush, Address to a Joint Session, 20 September, 2001.

55. Bush, State of the Union Address, 29 January, 2002.

56. John Ashcroft, Attorney General, Prepared Remarks for the US Mayors Conference October 25, 2001.

57. George W. Bush, Presidential Remarks to U.S. Attorneys Conference, Dwight David Eisenhower Office Building, November 29, 2001.

58. Bush, State of the Union Address, 29 January, 2002.

59. See Rahul Mahajan, Full spectrum dominance: U.S. power in Iraq and beyond (New York: Seven Stories Press, 2003); Alex Callinicos, The new mandarins of American power (Cambridge: Polity Press, 2003); Carl Boggs, "Introduction: Empire and globalization," in Carl Boggs, ed., Masters of war: Militarism and blowback in the era of American empire (New York and London: Routledge, 2003).

60. Quoted in Dilip Hiro, War without end: The rise of Islamic terrorism and global response (London and New York: Routledge, 2002), 391.

61. Quoted in Callinicos, The new mandarins, 44.

62. See Peter Lawler, (2002) "The 'good war' after September 11," Government and opposition 37: 2, 151-172.

63. James McDaniel, (2003) "Figures of evil: A triad of rhetorical strategies for theopolitics", Rhetoric and Public Affairs 6: 3, 539-550.

64. Bush, Address to a Joint Session, 20 September, 2001.

65. Ibid.

66. Bush, Remarks at Camp David, September 15, 2001.

67. Marc Grossman, Interview of Under Secretary of State, Digital Video Conference October 19, 2001 Washington, D.C. A trans-Atlantic digital interview with Londonbased journalists of Arab newspapers.

68. Donald H. Rumsfeld, Secretary of Defense, Interview with Wolf Blitzer, CNN, October 28, 2001.

69. See Andrew Hurrell. (2002) “There are no rules' (George W. Bush): international order after September 11," International Relations, 16: 2, 188.

70. Rumsfeld, Interview with editorial board of USA Today, October 24, 2001.

71. Bush, State of the Union Address, 29 January, 2002.

72. Grossman, Digital Video Conference, October 19, 2001.

73. Quoted in N. Wheeler. (2002) “Dying for 'enduring freedom': Accepting responsibility for civilian casualties in the war against terrorism", International Relations 16: 2, 210.

74. Bush, Address to a Joint Session, 20 September, 2001.

75. George W. Bush, Statement by the President on Military Strikes in Afghanistan, The Treaty Room, White House, October 7, 2001.

76. Bush, CEO Summit, Shanghai, 20 October, 2001.

77. Bush, Address to the Nation, 11 September, 2001.

78. Bush, Statement on Military Strikes, October 7, 2001.

79. George W. Bush, Radio Address by the President to the Nation, November 24, 2001.

80. Bush, Remarks to U.S. Attorneys Conference, November 29, 2001. 
81. George W. Bush, Press Conference, The East Room, Washington, DC, October 11, 2001.

82. Ibid.

83. Bush, Remarks to U.S. Attorneys Conference, November 29, 2001.

84. Quoted in Noam Chomsky (2003) "The war on terrorism," Perspectives On Evil and Human Wickedness 1: 2, 8-11.

85. Campbell, "Time is broken"; see also Joseba Zulaika, "The self-fulfilling prophesies of counterterrorism", Radical History Review 85, 2003, 191-99; Zulaika and Douglass, Terror and Taboo.

86. Hariman, "Speaking of evil," 513.

87. Murphy, "Our mission and our moment."

88. Campbell, "Time is broken."

89. Zulaika, "The self-fulfilling prophesies of counterterrorism," 193.

90. Boggs, "Introduction: empire and globalization," 10-11.

91. Campbell, "Time is broken."

92. Aune, "The argument from evil," 520.

93. See Ryan McGreal, (2003) "Paradigm Bait and Switch," Perspectives On Evil and Human Wickedness 1: 2, 99-107. 